\title{
ОЦЕНКА ФИТОПАТОГЕННЫХ ГРИБОВ ПО АКТИВНОСТИ ГИДРОЛИТИЧЕСКИХ ФЕРМЕНТОВ
}

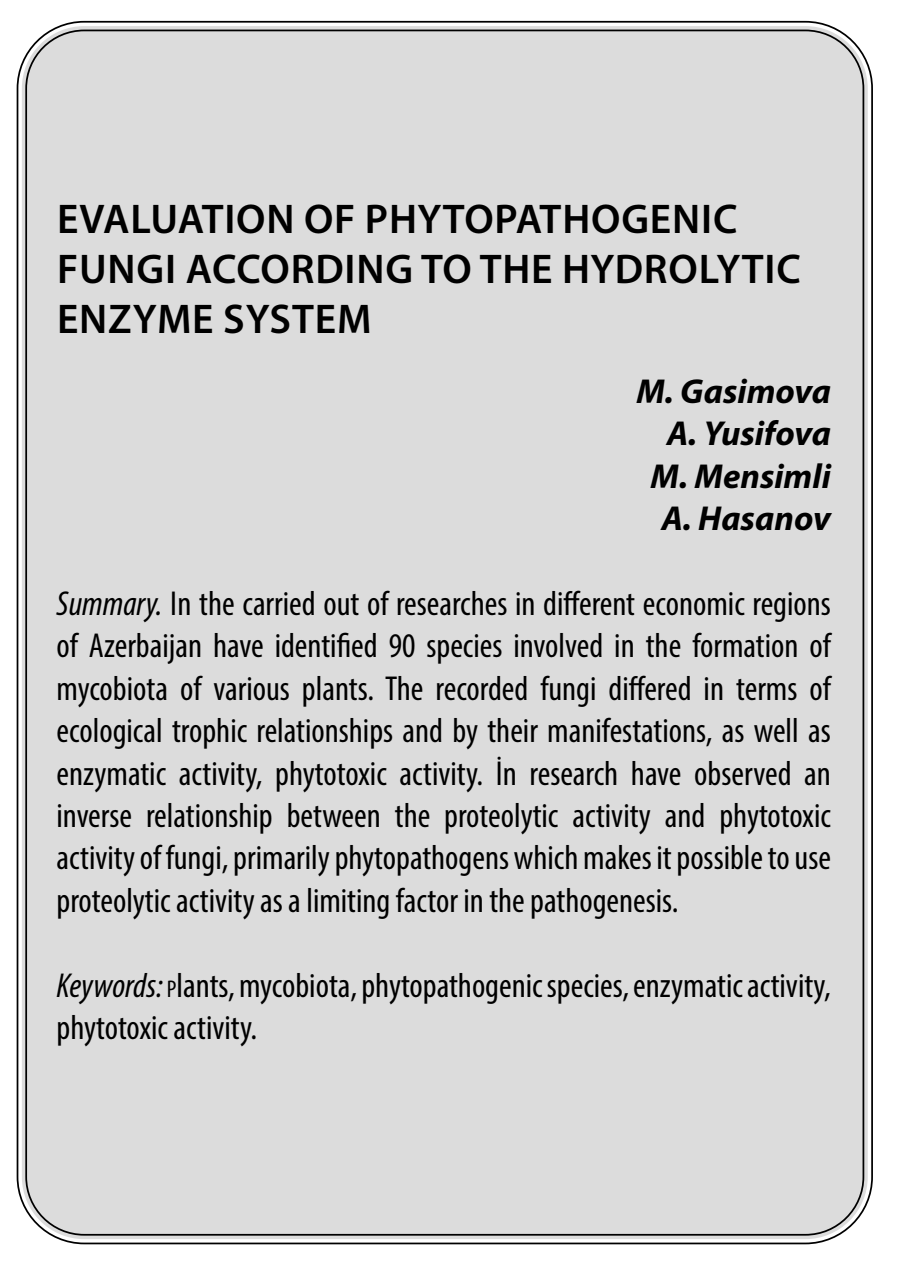

$\mathbf{K}$ ак известно, все растения, независимо от их назначения, являются одним из мест обитания грибов, которые в свою очередь, состоят с этими растениями в различных отношениях $[5,9]$. Для одной из таких форм отношений характерны патологии растений, вызываемые грибами [7]. В результате таких отношений могут существенно меняться морфологические, физиологические и биохимические свойства растений. В возникновении той или иной патологии растения предпосылкой и чуть ли не главным условием протекания процесса является проникновение клеток грибов в ткани растения-хозяина. Наличие у растительных клеток, также как и у всех эукариотических организмов, особой клеточной оболочки, препятствует легкому или без наличия особого механизма протеканию данного процесса. В этом отношении важное значение имеет ферментная система грибов, а в процессе патогенеза важно, чтобы возбудитель для проникновения во внутренние ткани хозяина
Гасымова Мехпара Ибрагим кызы

Доктор философии по биологии, и.о. дочента, Азербайджанский Аграрный университет (Гянджа) qmehpare@mail.ru

Юсифова Анаханым Амралы кызы Доктор философии сельскохозяйственных наук, доцент, Азербайджанский Государственный

Педагогический университет (Баку) azmbi@mail.ru

Мансимли Мужгян Руфат кызы Институт Микробиологии НАНА (Баку) masimlimujgan@gmail.com

Гасанов Азер Мирзасен оглы Научно-Исследовательских Институт Ветеринарии Министерства Сельского Хозяйства Азербайджанской

Республики

Аннотация. В исследованиях, проведенных в различных экономических регионах Азербайджана, выявлено 90 видов грибов, участвующих в формировании микобиоты растений различного назначения. Зарегистрированные грибы различались как по эколого-трофическим связям и формам их проявления, так и по ферментативной и фитотоксической активности. Исследования также показали обратную зависимость между протеолитической и фитотоксической активностью грибов, в первую очередь, фитопатогенов, что позволяет использовать протеолитическую активность как фактор, лимитирующий патогенез.

Ключевые слова: растения, микобиота, фитопатогенные виды, ферментативная активность, фитотоксическая активность.

синтезировал различные ферменты, катализирующие разрушение клеточной стенки [8], а точнее, составляющие ее полимеры. И как результат, не вызывает сомнений и то, что широкоспекторная ферментная система этого патогена играет важную роль в проникновении и роста патогена в тканях растения-хозяина.

Так, клеточная стенка растений, т.е. оболочка, имеет сложное строение, она содержит такие сложные полимеры как целлюлоза, лигнин, гемицеллюлоза, пектин, белок и др. [11-12], которые в том или ином растении характеризуются разным количеством, механизмом разложения и взаимодействием друг с другом. Например, разложение целлюлозы, гемицеллюлозы, пектина и крахмала в тканях растений происходит за счет гидролиза, а разложение лигнина происходит за счет окисления. Поэтому среди множества ферментов особый интерес представляют ферменты, которые катализируют 
разложение этих полимеров, а именно, гидролазы и оксиредуктазы[14]. Не вызывает сомнений и то, что патогены, не имеющие ферментной системы, катализирующей разложение соединений клеточной стенки растения-хозяина, слабее в борьбе за выживание и имеют меньший ареал распространения. Поэтому, изучение в этом аспекте организмов, особенно грибов, вызывающих у растений различные патологии, может иметь важное значение при разработке мер борьбы с патогенами [16.]. Так, одной из основных целей в борьбе с патогенами является его физическое уничтожение, что, в свою очередь, приводит к уничтожению видов, входящих в состав эпифитной микобиоты растения и играющих роль в почве и биологической продуктивности растений. По этой причине разработка метода избирательной борьбы с патогенами [10.] уже длительное время находится в центре внимания исследователей. Следует отметить, что такой подход, хотя и химического характера, достигнут в борьбе с сорняками. Изучение ферментной системы грибов может обещать новые перспективы такой борьбы. Так, наличие веществ, которые репрессируют синтез ферментов и подавляют каталитическую активность фермента, а также тот факт, что их количество и механизм действия связаны с особенностями самого гриба, были подтверждены в ряде исследований. Поэтому, целесообразно изучить ферментную систему грибов, а также их патогенных представителей, распространенных на растениях, выращиваемых в Азербайджане, что было реализовано на примере некоторых культурных и дикорастущих растений различных регионов Азербайджана.

\section{Материалы и метолы}

Исследования проводились в Апшеронском, Аранском, Гянджа-Газахском и Губа-Хачмазском экономических районах Азербайджана. Пробы были взяты с растений различного назначения (пищевые, кормовые, красильные, лекарственные, технические и др.), произрастающих и культивируемых в указанных регионах, а отобранные с них грибы были выделены в чистую культуру и проанализированы по видовому составу. В качестве питательных сред для выращивания грибов использовали агаризованное солодовое сусло (АСС), рисовый агар (РА), крахмальный (КА) и картофельный (КА) агар, агаризованную среду Чапека и Чапека-Докса. Приготовление сред, их стерилизацию и розлив в чашки Петри проводили согласно известным методам [4.]. Идентификация грибов проводилась на основе определителей, составленных на основе культурально-морфологических и физиологических признаков [7, 13, 15]. Для установления названия грибов использовались материалы с сайта Indexfungorum [17].

При определении ферментативной активности грибов для их культивирования использовали жидкую среду Чапека, культивирование проводили при $26{ }^{\circ} \mathrm{C}$ в течение 10 дней, а активность ферментов определяли в культуральной жидкости каждые 5 дней согласно соответствующим методикам.

Количество белка в ходе исследования определяли спектрофотометрическим методом [6]. В ходе исследования определяли активность целлюлазы (эндо-1,4- $\beta$-глюканазы), ксиланазы, протеазы, амилазы и пектиназы, согласно известными методами [1, 3].

Изучение фитотоксической активности отдельных видов грибов, входящих в состав микобиоты того или иного культурного растения, проводилось нижеотмеченным способом. Грибы после выращивания в жидкой среде Чапека фильтруют и отделяют полученную биомассы. Используемые семена (при условии, что от каждого растения берется 100-150 семян) замачивают в этой культуральной жидкости на 24 часа. В контрольном варианте используется стерильная среда Чапека. Затем семена помещают на увлажненную фильтровальную бумагу и проращивают при комнатной температуре $\left(20-22^{\circ} \mathrm{C}\right)$ в течение 7 дней. Фитотоксическая активность грибов (в\%) также определяется по формуле, где $\mathrm{P}$ - это фитотоксическая активность, $\mathrm{n}$ - количество не проросших семян, а $\mathrm{N}$ - общее количество взятых семян. Во всех случаях в каждом повторности количество взятых семян составляло 100 единиц.

В ходе исследования все эксперименты проводились В 4-6 повторностях, результаты статистически обрабатывались [2], и во всех случаях достоверными считались данные, соответствующие формуле $\mathrm{m} / \mathrm{M}=$ $\mathrm{P} \leq$ 0,05 (где $\mathrm{M}$ - среднее значение, $\mathrm{m}$ - стандартное отклонение, Р — критерий Стьюдента).

\section{Результаты \\ и их обсужАения}

В проведенных в различных экономических регионах Азербайджана исследованиях было зарегистрировано около 90 видов грибов. По эколого-трофическим связям среди них были обнаружены как факультативные, так и истинные (биотрофы и сапроторофы). Наличие среди них фитопатогенных, токсигенных, оппортунистических и аллергенных грибов было подтверждено в ходе исследования. В связи с этим в ходе дальнейшего процесса исследования было сочтено целесообразным изучить ферментативную активность 113 штаммов 25 видов грибов.

В результате проведенных исследований было установлено, что все использованные в исследовании грибы обладают той или иной степенью гидролазной активности, и привлекает внимание разность 
Таблица 1. Ферментативная активность грибов, входящих в состав микобиоты некоторых красильных растений западного региона Азербайджана(Ед/мл)

\begin{tabular}{|c|c|c|c|c|c|c|}
\hline № & Виды (число штаммов) & Целлюлаза & Ксиланаза & Амилаза & Пектиназа & Протеаза \\
\hline 1 & Aspergillusflavus (5) & $1,1-2,1^{*}$ & $20,1-28,7$ & $1,7-2,6$ & $5,6-7,3$ & $3,6-7,1$ \\
\hline 2 & A. fumigatus (5) & $1,0-1,7$ & $17,8-24,3$ & $2,3-3,8$ & $4,5-7,5$ & $2,7-6,5$ \\
\hline 3 & A. niger (5) & $2,0-4,5$ & $35,3-42,5$ & $3,8-5,3$ & $9,6-11,5$ & $4,6-7,2$ \\
\hline 4 & A.ochraceus (4) & $0,4-0,7$ & $13,2-17,6$ & $1,2-2,3$ & $7,1-8,9$ & $3,2-4,5$ \\
\hline 5 & Alternariaalternata (4) & $0,9-1,7$ & $12,7-24,5$ & $0,7-1,3$ & $3,1-5,1$ & $2,2-4,7$ \\
\hline 6 & A. solani (4) & $0,5-1,2$ & $17,8-30,1$ & $0,5-0,8$ & $2,7-4,3$ & $1,9-5,7$ \\
\hline 7 & Botrytis cinerea (4) & $0,5-0,7$ & $21,2-24,6$ & следы & $1,2-2,5$ & $0,7-1,2$ \\
\hline 8 & F.avenaceum (8) & $1,1-1,6$ & $16,4-22,9$ & $1,4-2,2$ & $1,5-3,5$ & следы \\
\hline 9 & F.gibbosum (5) & $0,8-1,3$ & $15,6-25,3$ & $1,8-3,0$ & $2,6-4,8$ & $0,3-0,8$ \\
\hline 10 & F. moniliforme (5) & $0,9-1,3$ & $25,3-35,4$ & $2,7-4,2$ & $3,1-5,4$ & $0,2-0,9$ \\
\hline 11 & F.oxysporum (5) & $0,7-1,2$ & $20,2-31,4$ & $2,3-3,5$ & $2,3-4,6$ & следы \\
\hline 12 & F. semitectum (4) & $1,0-1,3$ & $16,7-25,4$ & $1,8-2,6$ & $2,3-3,9$ & $0,1-0,2$ \\
\hline 13 & V. dahliae (5) & $0,3-0,5$ & $18,9-23,5$ & $1,1-1,5$ & $3,5-6,7$ & $0,8-1,1$ \\
\hline 14 & V. albo-atrum (4) & $0,2-0,4$ & $15,4-20,3$ & $0,9-1,4$ & $3,0-5,2$ & $0,6-1,1$ \\
\hline 15 & P.martensii (4) & $0,2-0,5$ & $23,4-31,3$ & следы & $2,9-6,1$ & $2,3-4,5$ \\
\hline 16 & P.cuslopium (5) & $0,3-0,7$ & $26,5-34,5$ & $1,2-2,4$ & $3,4-7,4$ & $1,1-2,2$ \\
\hline 17 & P. chrysogenum (5) & $0,8-1,3$ & $18,9-23,4$ & $0,6-1,4$ & $2,1-4,3$ & $2,9-4,6$ \\
\hline 18 & C.herbarum (4) & $1,1-1,5$ & $19,3-28,3$ & $0,3-0,8$ & $2,6-4,3$ & $1,4-1,9$ \\
\hline 19 & Asc.pisi (4) & $0,9-1,4$ & $17,2-23,2$ & $0,7-1,4$ & $2,6-4,2$ & $1,3-1,7$ \\
\hline 20 & Asc. Betae (3) & $0,5-1,0$ & $14,2-19,4$ & $0,3-0,8$ & $1,8-3,7$ & $1,2-1,9$ \\
\hline 21 & Rh. Nigricans (4) & $1,3-1,6$ & $18,2-21,3$ & $1,1-1,5$ & $2,1-4,1$ & $4,4-5,7$ \\
\hline 22 & M. mucedo (5) & $1,1-1,5$ & $19,6-28,9$ & $0,9-1,3$ & $2,4-3,3$ & $6,4-7,6$ \\
\hline 23 & M.plumbeus (3) & $0,9-1,7$ & $17,2-24,3$ & $0,7-1,5$ & $1,6-3,9$ & $3,6-5,9$ \\
\hline 24 & T.lignorum (5) & $2,3-4,1$ & $29,1-36,7$ & $0,1-0,5$ & $1,2-1,9$ & $4,1-5,7$ \\
\hline 25 & T.viride (4) & $2,0-3,4$ & $25,6-34,4$ & $0,2-0,4$ & $1,1-1,6$ & $3,2-5,4$ \\
\hline
\end{tabular}

*- все результаты статистически обработаны, и во всех случаях $\mathrm{P} \leq 0,048$

количественных показателей активности ферментов этих грибов (таблица 1).

Этот факт, характеризующийся штаммовыми различиями, также следует рассматривать как фактор, играющий важную роль в патогенезе грибов. Постараемся подтвердить это следующим.

Как видно из таблицы (табл. 1), некоторые штаммы обладают высокой ферментативной активностью и по количественным показателям не отстают в этом аспекте от непатогенных штаммов (входящих В эпифитную микобиоту растений), считающихся активными продуцентами ферментов. Однако данные таблицы не позволяют уточнить роль отдельных ферментов в патогенезе, и нет четкой зависимости между опасностью грибов и высоким уровнем ферментативной активности. Например, штаммы грибов рода Fusarium, вызывающие фузариоз растений, по протеолитической активности уступают A. niger, который не считается опасным фитопатогеном.
С другой стороны, грибы рода Trichoderma, которые относятся к эпифитной микобиоте растений, обладают высокой целлюлолитической активностью. Количество целлюлозы среди полимеров, составляющих растительный покров, является достаточным, а точнее, превосходящим и поэтому создается впечатление, что она легче проникает в растение. Однако, как уже отмечалось, грибы, принадлежащие к роду Trichoderma, относятся к эпифитной микобиоте растений и в то же время имеют антагонистические отношения с фитопатогенами, благодаря чему из них получают препараты для улучшения фитосанитарного состояния почв.

Поэтому в ходе исследований было целесообразным выяснить характер взаимосвязи фитотоксической и ферментативной активности грибов. С этой целью 100 семян каждого растения выдерживались в течение 12 дней в культуральной жидкости гриба, культивированного в среде Чапека в течение 7 дней. По окончании этого периода семена помещают 
Таблица 2. Влияние культуральной жидкости грибов на всхожесть некоторых растений (\%)

\begin{tabular}{|c|c|c|c|c|c|c|}
\hline Штаммы & Пшеница & Огурец & Арбуз & Ячмень & Фасоль & Томат \\
\hline Aspergillusflavus M-14 & 79 & 74 & 84 & 75 & 82 & 80 \\
\hline A. fumigatus M-16 & 70 & 65 & 76 & 69 & 73 & 78 \\
\hline A. niger $M-25$ & 80 & 76 & 87 & 82 & 78 & 77 \\
\hline A.ochraceus M-31 & 78 & 75 & 85 & 79 & 72 & 81 \\
\hline Alternariaalternata A-07 & 65 & 63 & 67 & 72 & 69 & 64 \\
\hline A. solani A-14 & 61 & 51 & 56 & 64 & 55 & 53 \\
\hline Botrytis cinerea A-21 & 49 & 43 & 54 & 45 & 52 & 49 \\
\hline Fusariumavenaceum E-06 & 30 & 34 & 36 & 32 & 40 & 50 \\
\hline F.gibbosum E-45 & 39 & 40 & 42 & 37 & 44 & 49 \\
\hline F. moniliforme E-73 & 38 & 37 & 39 & 39 & 40 & 43 \\
\hline F.oxysporum E-96 & 35 & 29 & 37 & 36 & 34 & 32 \\
\hline F. semitectum E-75 & 41 & 35 & 44 & 40 & 39 & 43 \\
\hline V. albo-atrum E-122 & 50 & 49 & 48 & 52 & 52 & 48 \\
\hline Vertisillium dahlia E-121 & 45 & 47 & 52 & 48 & 49 & 41 \\
\hline P.martensii A-32 & 67 & 64 & 73 & 70 & 72 & 68 \\
\hline P.cuslopium A-38 & 59 & 56 & 64 & 54 & 63 & 53 \\
\hline P. chrysogenum A-40 & 72 & 68 & 75 & 70 & 74 & 75 \\
\hline C.herbarum A-56 & 65 & 62 & 70 & 60 & 68 & 65 \\
\hline Asc.pisi A-39 & 65 & 60 & 64 & 68 & 63 & 67 \\
\hline Asc. betaeA-38 & 61 & 59 & 62 & 70 & 64 & 63 \\
\hline Rh. nigricans E-97 & 76 & 79 & 81 & 78 & 80 & 82 \\
\hline M. mucedo E-89 & 85 & 86 & 89 & 87 & 90 & 92 \\
\hline M.plumbeus E-83 & 79 & 80 & 82 & 83 & 78 & 88 \\
\hline T.lignorum F-12 & 97 & 95 & 97 & 95 & 96 & 92 \\
\hline T.viridei F-15 & 94 & 95 & 94 & 90 & 91 & 89 \\
\hline Контроль & 91 & 92 & 91 & 90 & 89 & 88 \\
\hline
\end{tabular}

в климатическую камеру и в течение 30 дней наблюдают за их прорастанием. Полученные результаты показали, что грибы с высокой протеолитической активностью не обладают высокой фитотоксической активностью (таблица .2).

Например, протеолитическая активность гриба Verticillium dahliae E-121 в 5,5 раз ниже, чем у AspergiIlus flavus M-14, но сравнение результатов, полученных при прорастании семян, показывает, что действие первого намного эффективнее, почти в 2 раза. В остальных вариантах чётко проявляются аналогичные результаты, т.е. существует обратная зависимость между протеолитической и фитотоксической активностью, что позволяет использовать протеолитическую активность как лимитирующий фактор в патогенезе.
Как было отмечено выше, протеолитические ферменты деградируют белки путем гидролиза. Точнее, протеолитические ферменты разрушают пептидные связи, участвующие в образовании белков, и в конечном итоге расщепляют их на аминокислоты, т.е. белки выступают в роли субстрата для протеолитических ферментов. Все ферменты имеют белковую природу и эти ферменты также могут играть роль субстратов для протеаз, поэтому высокая активность протеолитических ферментов отрицательно влияет на активность других ферментов, что приводит к снижению активности и, следовательно, к затруднению проникновения их в клетку. Всё это позволяет говорить о том, что в будущем будет эффективно учитывать этот факт при разработке мер борьбы по нейтрализации или ограничении активности фитопатогенных грибов.

\section{ЛИТЕРАТУРА}

1. Клесов А.А., Рабинович М. Л., Синицын А. П. и др. Ферментативный гидролиз целлюлозы: 1. Активность и компонентный состав целлюлазных комплексов из различных источников. //Биоорганическая химия, 1980, т. 6, С. 1225-1241.

2. Кобзарь А. И. Прикладная математическая статистика. М.: ФИЗМАТЛИТ, 2006, 816 с. 
3. Лабораторный практикум по технологии ферментных препаратов. М.: Легкая и пищевая промышленность, 1982, 240 c.

4. Методы экспериментальной микологии/Под. ред. Билай В. И. Киев: Наукова думка, 1982, 500с.

5. Сафаралиева Э.М., Алиева Г. Р., Рзаева А. Л., Мамедова Ф. Р., Бахшалиева К. Ф. Изменение видового состава грибов, распространенных на различных ценозах в условиях Азербайджана //, Современная наука: актуальные проблемы теории и практики. Серия: Естественные и Технические Науки, 2020, № 02, C. $52-57$

6. Практикум по биохимии (Под. ред. Н. П. Мешковой и С. Е. Северина.). М: МГУ, 1979, 430 с.

7. Саттон Д., Фотергилл А., Риналди М. Определитель патогенных и условно патогенных грибов.М.: Мир, 2001, 486с.

8. Amit K.C., Shubha C., Sushmita C., Shridha C. In vitro and in vivo production of polygalacturonase, polymethylgalacturonase and cellulase enzymes by Alternaria solani at different incubation periods.// African Journal of Plant Science, 2014, 8(5):248-253.

9. Archana J., Surendra S., Qin W., Yuanfu L. \&Jingshan Sh. A review of plant leaf fungal diseases and its environment speciation.// Bioengineered, 2019, 10,1:409-424

10. Foddai, A.C.G., Grant, I. R. Methods for detection of viable foodborne pathogens: current state-of-art and future prospects.// Appl Microbiol Biotechnol., 2020, 104, 4281-4288

11. Franková, L., Fry, S. C. Biochemistry and physiological roles of enzymes that'cut and paste' plant cell-wall polysaccharides.// Journal of Experimental Botany, 2013, v. 64 , is. 12, p. $3519-3550$

12. Gilbert H. J. The Biochemistry and Structural Biology of Plant Cell Wall Deconstruction.// Plant Physiology, 2010, Vol. 153, p. 444-455

13. Kirk P.M., Cannon P. F., Minter D. W. et al. Dictionary of the fungi. 10-th edition. UK, 2008, $747 \mathrm{p}$.

14. Robinson P. K. Enzymes: principles and biotechnological applications.// Essays Biochem.,2015, 59:1-41.

15. Samson R. A., Pitt J. I. Integration of modern taxonomic methods for Penicillium and Aspergillus classification. Amsterdam: Harwood Publishers, 2000, 510p.

16. Shuping, D.S.S., Eloff J. N. The use of plants to protect plants and food against fungal pathogens: a review//Afr J Tradit Complement Altern Med., 2017, 14(4): 120-127.

17. www.indexfungorum.org/Names/fungic.asp

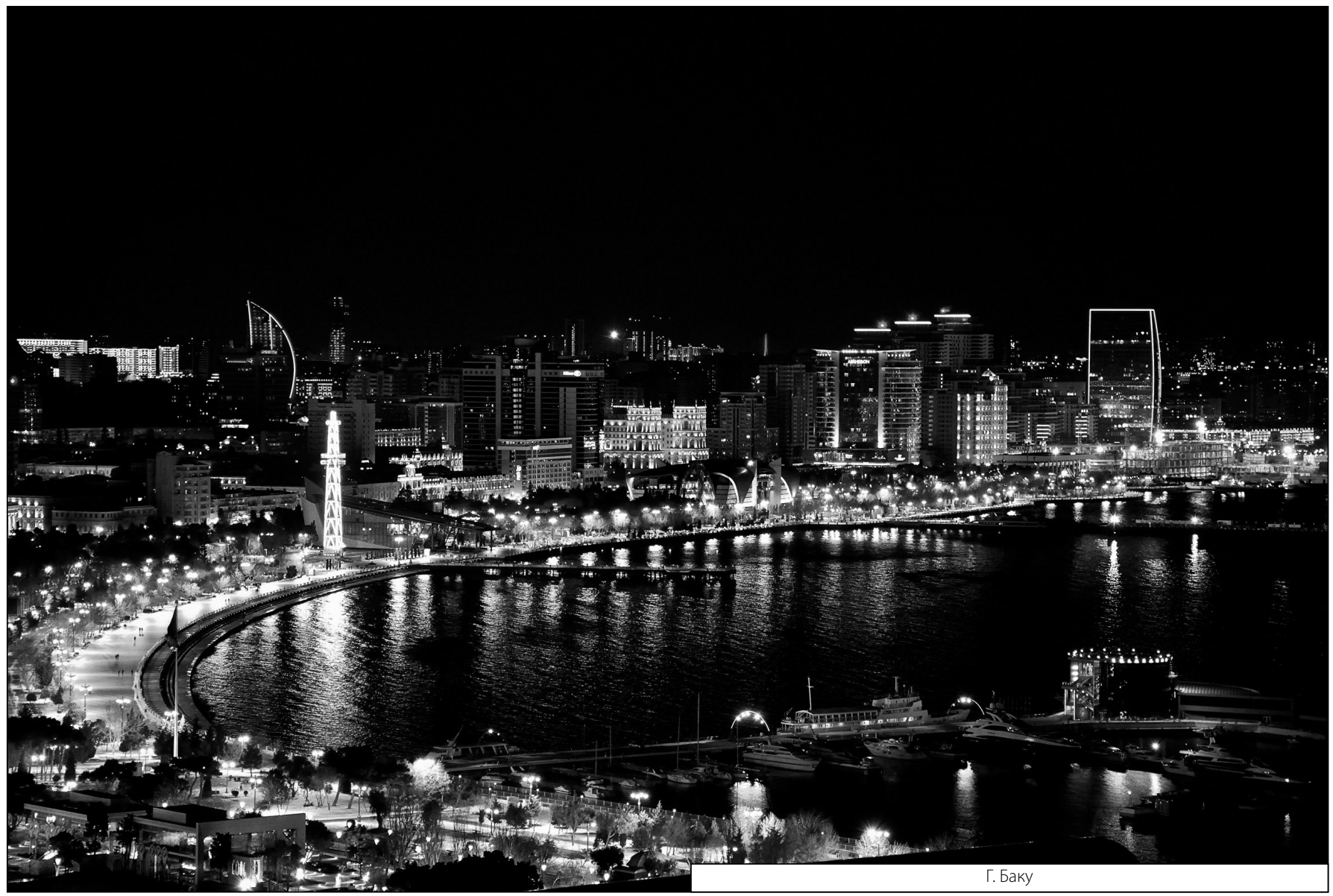

